\title{
STEEL POEKEE-99001705
}

Ision:

HE STEEL INDUSTRY WILL

EMAIN A STRONG AND VIBRANT

ECTOR OF THE U.S. ECONOMY,

ROVIDING HIEH-QUALITY,

ALUE-ADDED PRODUCTS TO A

VIDE ARRAY OF CUSTOMERS IN

N ENVIRONMENTALLY FRIENDLY,

OST-EFFECTIVE MANNER.

ITEEL: A NATIONAL

IESOURCE FOR THE FUTURE MERICAN IRON AND STEEL NSTITUTE

:TEEL MANUFACTURERS ISSOCIATION

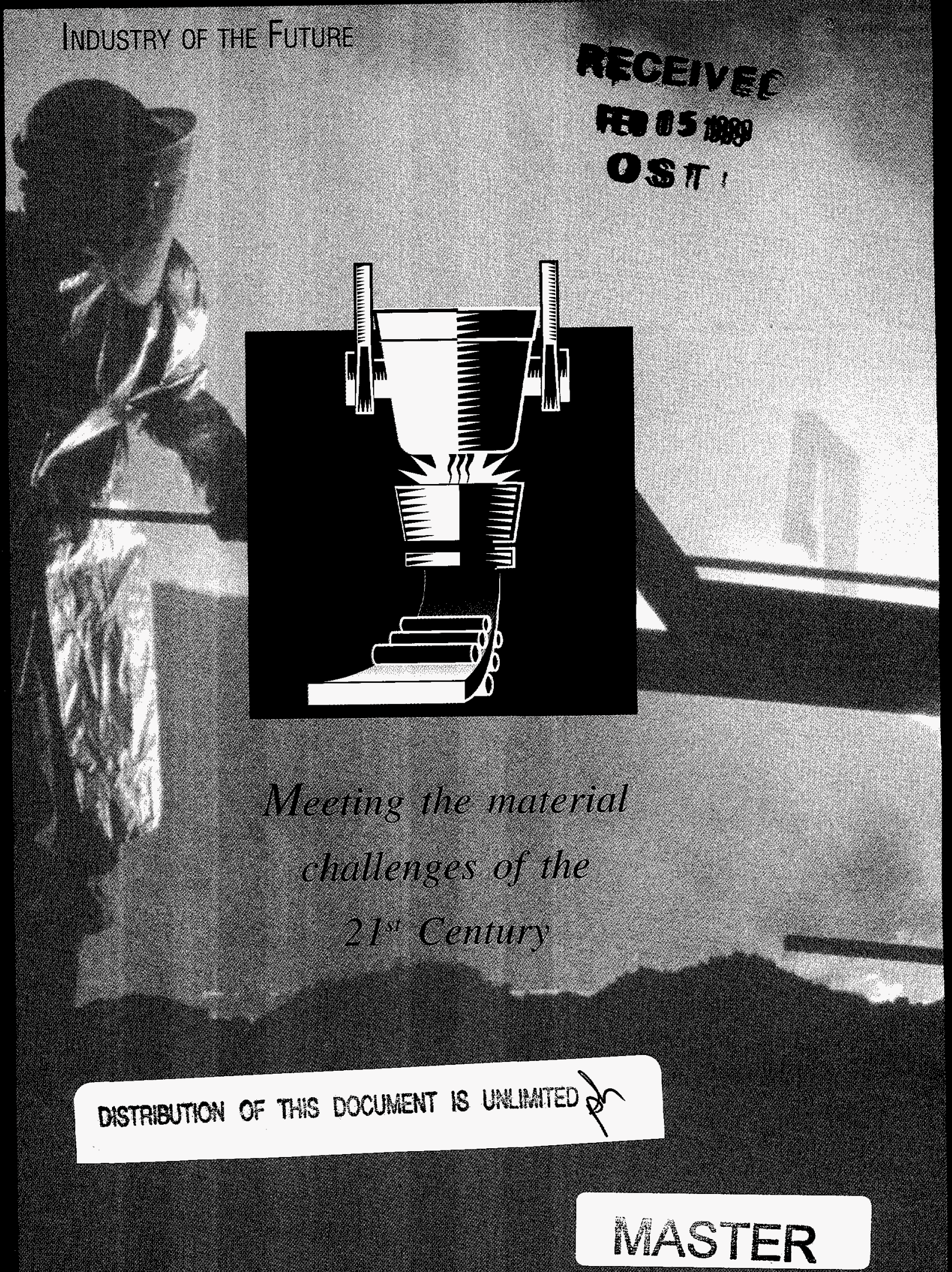




\section{THE VISION}

\section{Industry vision provides framework for cooperative $R \& D$}

For over a century, the U.S. steel industry has led the global market with advances in technology, product development, and marketing. Industry leaders recognize both the opportunities and challenges they face as they head into the $21^{\text {st }}$ century, and that cooperative $R \& D$ is key to their success.

In a unique partnership, steel industry leaders have teamed with the U.S. Department of Energy's Office of Industrial Technologies (OIT) to focus on innovative technologies that will help to strengthen the competitive position of the U.S. steel industry and, at the same time, further important national goals. This industry-led partnership, the Steel Industry of the Future, promotes technologies that optimize the use of energy and materials in operation and reduce wastes and energy-related emissions.

\section{Partnerships for the Future}

Led by the American Iron and Steel Institute (A|SI) and the Steel Manufacturers Association (SMA), industry leaders began by developing a unified vision for the next 20 years: to provide highquality, value-added products to a wide array of customers in an environmentally friendly, cost-effective manner, while leading the world in innovation and technology.

Continued global leadership in materials markets will require the combined resources of industry, universities, and government laboratories. The steel industry vision provided a framework for the next step in the Industries of the Future process, the development of a technology roadmap designed to facilitate collaborative $R \& D$ on advanced processes and technologies for the steel industry.

\section{THE ROADMAP}

\section{Roadmaps define technology priorities and performance targets}

Developed through a highly interactive process led by AISI and SMA, the Steel Technology Roadmap outlinies a strategy for achieving the goals established in the industry vision (see www.oit.doe.gov/steel). The roadmap establishes a focused R\&D agenda, identifying the technologies required to make the vision a reality.

By articulating its technology strategy, the U.S. steel industry hopes to motivate companies, the academic community, and other Federal agencies to align their research efforts with the high-priority needs identified by industry. The roadmap identifies numerous research thrusts required to meet performance targets. Research projects may be funded through single companies, industry collaborations, or industry-government partnerships. OIT selectively co-funds projects that address its mission of improving energy efficiency and preventing pollution.

Partnering for a Clean and Competitive Industry of the Future

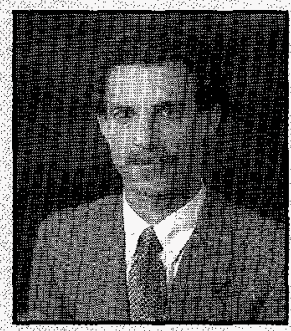

Dan W. Recher Assistant Secretary Energr EffictencY AND RENEWABLE ENERGY
Our nation's strength is based in large part on our access to affordable and reliable energy. As we move into the new millennium, our mission is to clevelop and deploy new ways to meet our energy needs and improve our environmental quality through use of renewable energy and increased energy efficiency.

Through the Industries of the future Program, the Office of Energy Efficiency and Renewable Energy is actively engaged with U.S. industry to capture energy and natural resources savings by developing and deploying clean and energy efficient technologies and practices. Working with the nation's most energy Intensive industries, we are mapping a vision of the energy future of American industry and developing the technology needed to implement that vision. This profile describes a few of the many ways that the DOE-industry alliance is working towards a more competitive future for $\mathrm{US}$ S. industry and our nation. 


\section{DISCLAIMER}

This report was prepared as an account of work sponsored by an agency of the United States Government. Neither the United States Government nor any agency thereof, nor any of their employees, makes any warranty, express or implied, or assumes any legal liability or responsibility for the accuracy, completeness, or usefulness of any information, apparatus, product, or process disclosed, or represents that its use would not infringe privately owned rights. Reference herein to any specific commercial product, process, or service by trade name, trademark, inanufacturer, or otherwise does not necessarily constitute or imply its endorsement, recommendation, or favoring by the United States Governmeat or any agency thereof. The views and opinions of authors expressed herein do not necessarily state or reflect those of the United States Government or any agency thereof. 


\section{DISCLAIMER}

Portions of this document may be illegible in electronic image products. Images are produced from the best available original document. 


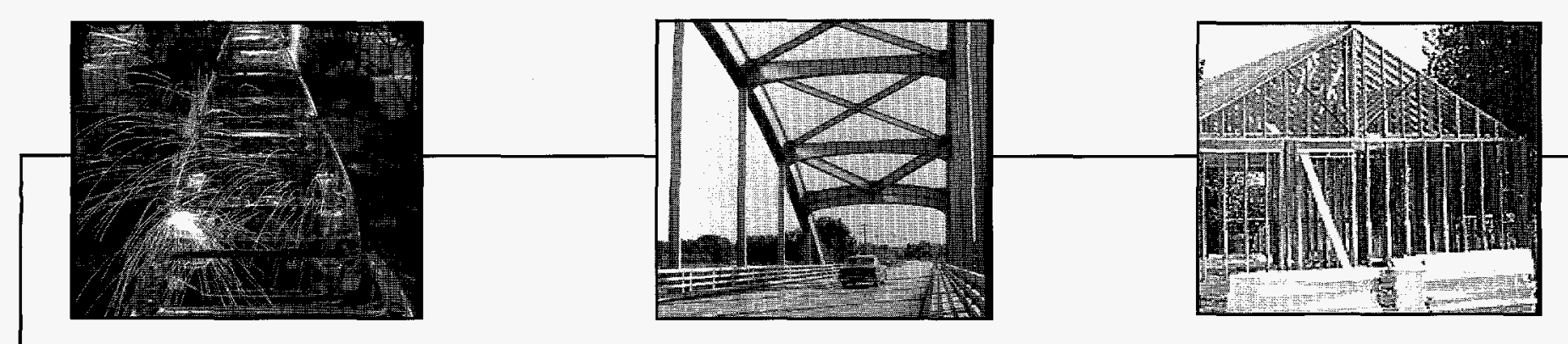

\section{Selected high-priarity research needs}

The roadmap reflects the needs of the total industry, including both integrated and secondary steelmaking, manufacturers of semifabricated products, and end-use customers, as well as the research community.

\section{Process Development}

The steel industry will continue to seek improvements in the resource efficiency, productivity, and cost-effectiveness of its processes. The competitiveness of U.S. steelmakers will be enhanced through the development of alternative ironmaking technologies and advanced strip casting.

IRON UNIT RECYCLING

Recovery of the iron content of all classes of scrap and steel mill by-products will be maximized. New processes will allow recycling of ironmaking and steelmaking dusts and sludges into the process with no deleterious effects on the final product. Production of steel from scrap will approach $70 \%$.

\section{ENVIRONMENT}

Processes will be designed to avoid pollution rather than control and treat it. The industry will move toward total enclosure and zero emissions and waste.

\section{Addressing future developments}

The Steel Industry Technology Roadmap will be revised and updated periodically to reflect changing market and technical issues, and to ensure that the research priorities remain relevant to customer needs.

\section{STEEL INDUSTRY OF THE FUTURE}

\section{Novel public-private partnerships}

The Industries of the Future process is driven by industry. Through technology roadmaps, industry participants set technology priorities, assess the progress of R\&D, and ultimately lead the way in using the results. This new approach to public-private partnerships ensures the most strategic allocation possible of limited resources for the development of new technologies.

OIT's role is to help facilitate the Industries of the Future process and to support the development and deployment of technologies that will shape the future of the steel industry. Part of this role is to encourage industry to undertake long-term, sector-wide technology planning and to selectively co-invest with OIT in collaborative $R \& D$ efforts that match OIT's Federal missions.

Through this partnership, OIT provides streamlined access to the resources and capabilities of the National Laboratories and other Federal programs that share interests with the steel industry. Supporting this streamlined access is the Laboratory Coordinating Council (www.oit.doe.gov/lcc/lccintro.html), which produces detailed documentation of current and past research projects and laboratory capabilities that correspond to steel technology needs.

\section{TAKING ACTION BASED ON INDUSTRY'S VISION}

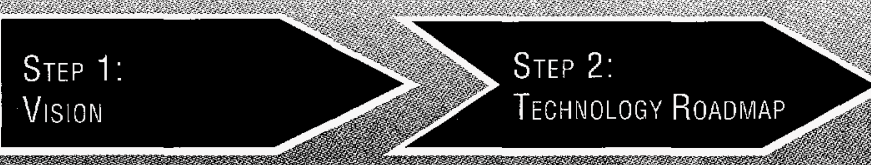

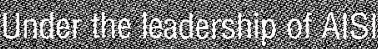

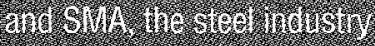

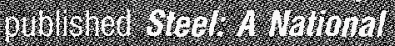

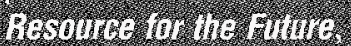

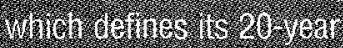
visterg of trow to math thit and

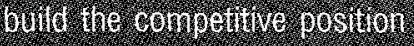

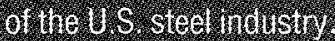

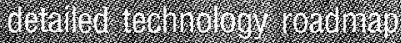

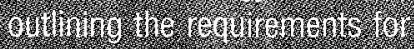

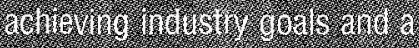

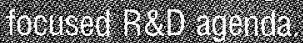

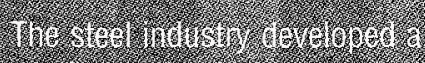

STEP 3: R\&D PARTNERSHIPS

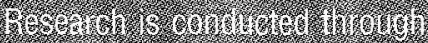
X바.

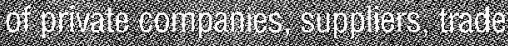

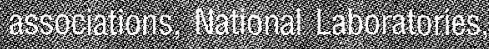

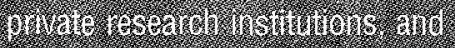

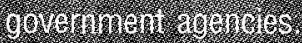




\section{PORTFOLIO HIGHLIGHTS}

\section{Industry of the Future projects advance steel vision}

Through the Industries of the Future process, steel industry leaders can ensure the most strategic possible allocation of limited resources for technology development. The process encourages companies, the academic community, and National Laboratories to re-focus their research efforts to conform with the needs of the industry. OIT selectively co-funds R\&D efforts, targeting potentially high-payoff technologies where risks are too high or results too long-term to attract adequate private-sector investment.

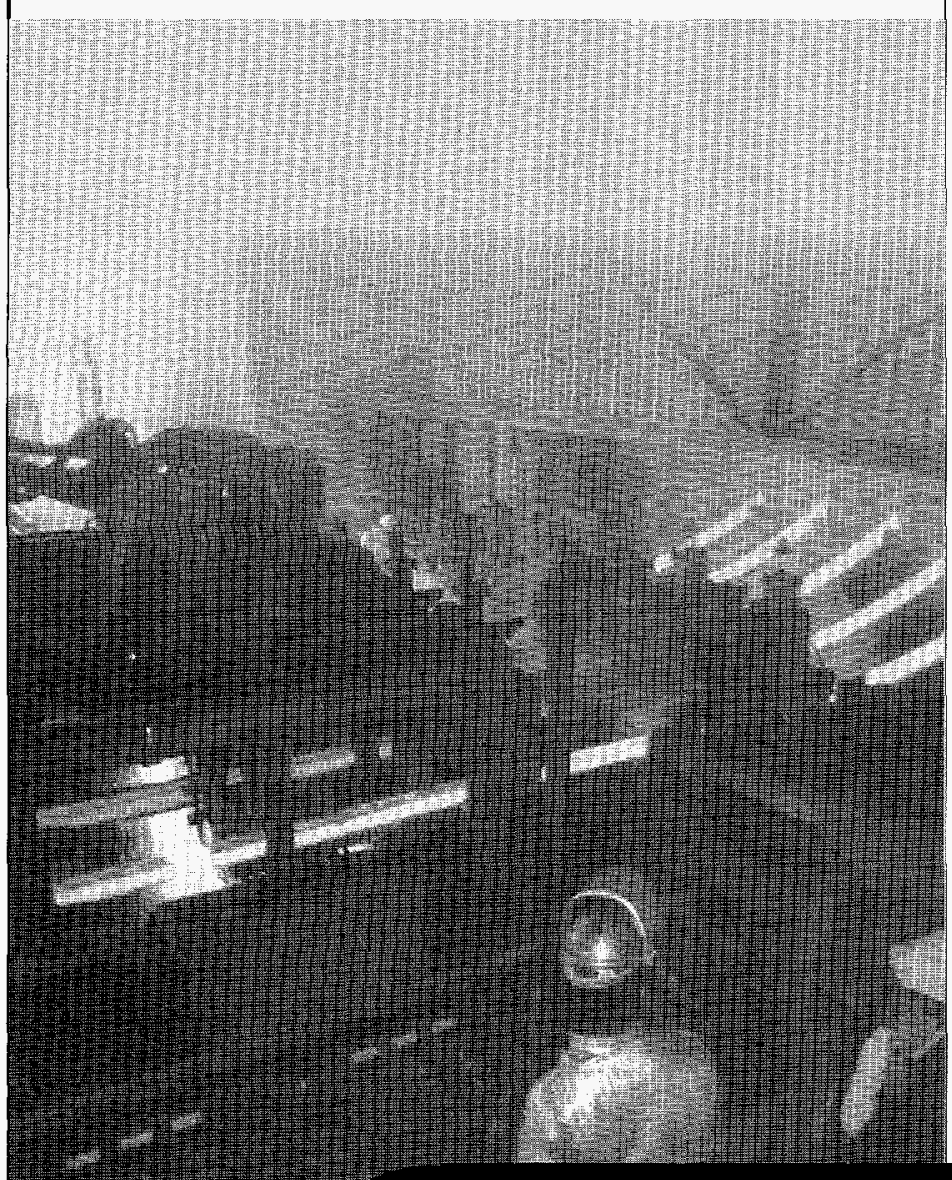

The following projects represent a sampling of the Steel Industry of the Future initiatives currently under way.

\section{Process Development}

Strip Casting: New Routes to Steel Sheet

Steel companies are partnering with academia to evaluate the use of strip-cast material in conventional applications. The project will give partner companies direct experience with representative stripcast materials to determine the processing steps necessary to ensure that the industry can use strip-cast material to produce competitive products.

PARTMERS

AK Steel

AISI

British Steel Research Labs

Carnegie Mellon University

LTV Steel Company

National Steel

SMS Steel

USX-US Steel Group
HOT OXYGEN INJECTION

The direct injection of hot (around 3,000 ${ }^{\circ}$ ) oxygen into the blast furnace, combined with injection of fossil fuels, can improve the efficiency of molten iron production. The process has already been demonstrated at the pilot scale.

PARTNERS

AISI

Praxair, Inc.

\section{Environment}

nOx Emission Reduction by Oscillating Combustion Oscillating combustion offers increased efficiency, higher productivity, and reduced NOx emissions from the high-temperature furnaces used in the steel industry, whether they are fired with ambient air, preheated air, enriched air, or industrial oxygen.

Partners

Air Liquide Bethlehem Steel CeramPhysics, Inc. Columbia Gas Dist. Co.
Gas Research Institute GT Development Corp. Institute of Gas Technology Southern California Gas

The Industries of the Future process enables competitors, suppliers, and customers to work together to solve precompetitive problems. This approach reduces the cost and risk of $R \& D$. 
Minimizing NOX Emissions from By-product Fuels in Steelmaking Project partners are working to provide an understanding of the mechanisms controlling the formation of NOx emissions during the combustion of steelmaking by-product fuels, and investigating possible low-cost control options to minimize the NOx emissions.

PARTNERS

Geneva Steel Corporation

Reaction Engineering International

University of Utah

\section{Iron Unit Recycling}

Recycling of Waste Oxides in Steelmaking Furnaces

This project will develop an effective operating practice for recycling of waste oxide agglomerates in the steelmaking furnace, resulting in improved energy efficiency and reduced steel production costs.

PARTNERS

AISI

Carnegie Mellon University

Effects of Residuals in Carbon Steel

Development of specifications for maximum allowable content of residual elements in steel products and in recycled scrap will allow industry to increase its use of recycled scrap.

PARTNERS

AlSI

AK Steel

Bethlehem Steel

Ipsco, Inc.

LTV Steel

National Steel

Stelco, Inc

The Timken Company

U.S. Steel Research

Weirton Steel Corporation

Removal of Residuals in Carbon Steels

This work will determine the feasibility of tin removal and ultimately develop a process to allow a greater portion of tincontaining scrap to be used for steel production.

PARTNERS

American Iron and Steel Institute

Dofasco, Inc.

U.S. Steel Research

\section{Case Studies}

Optical sensors and controls for improved basic oxygen furnace (BOF) operations

Optical sensors for gas-phase composition and temperature measurement can optimize basic oxygen furnace (BOF) operation through dynamic process control, provide real-time diagnostic tools for post-combustion and melt decarburization, provide real-time measurement of dust loading in the off-gas, and minimize excess thermal loading of BOF vessel refractory by monitoring off-gas temperature.

Optical sensors for bath temperature measurement and range-finding can calculate bulk temperature from slag temperature using optical image-based techniques, monitor hot spot emissions during oxygen blowing to aid in endpoint control, provide real-time video imaging of the furnace interior (refractory life), and measure the bath height for improved control of lance operating practices.

\section{Benefits}

- Optimizes process control and standardizes operating procedures

- Reduces energy usage via real-time temperature measurement and process end-point control

- Reduces BOF maintenance requirements

- Reduces oxygen use and minimizes BOF dust production

\section{Temperature measurement of galvanneal steel} In-process measurement of galvanneal steel strip temperatures can improve the energy efficiency and redice the costs of producing galvannealed steel. A prototype system based on thermographic phosphor technology has been successfully demonstrated in an operating plant This system can achieve a temperature neasurement accuracy of $+-5^{\circ} \mathrm{F}$ in harsh plant environments.

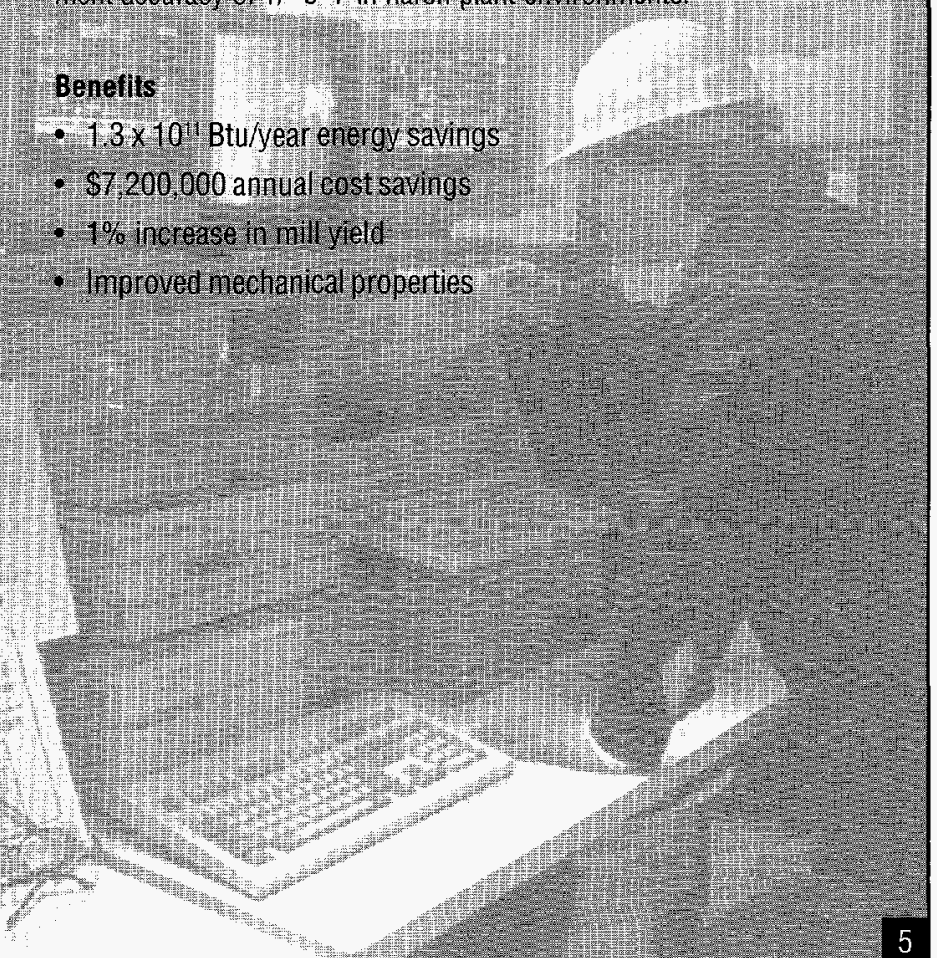




\section{Case Studies}
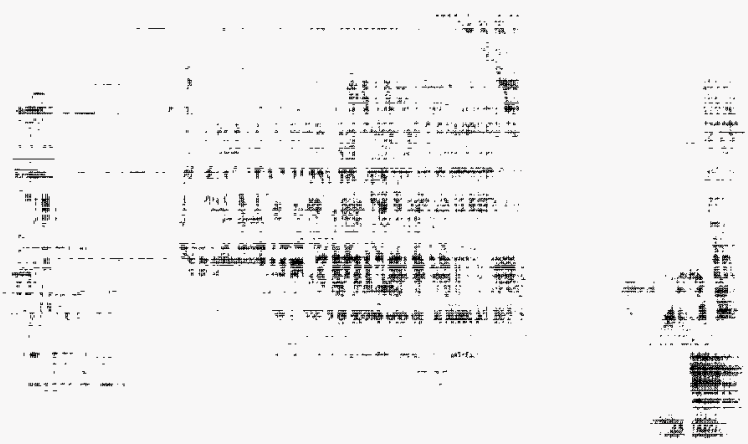

$\mathrm{Ni}_{3} \mathrm{Al}$ materials for rolls in steel reheat furnaces

The surface finish of steel slabs is affected by the condition of transfer rolis in high-temperature furnaces. Transfer rolls made of nickel aluminide $\left(\mathrm{Ni}_{3} \mathrm{Al}\right)$ have superior high-temperature oxidation resistance, strength, creep, and fatigue resistance. Results from inplant testing of $\mathrm{Ni}_{3} \mathrm{Al}$ rolls in a production steel reheat furnace have demonstrated the improved surface of slabs processed with these rolls.

\section{Benefits}

- Higher productivity and less down time

- Lower rework requirements

- Improved product quality

\section{Motor upgrades reduce scrubber energy costs at steel mill}

Bethlehem Steel Corporation installed a variable frequency drive (VFD) and made associated equipment modifications to the induced draft fans that remove gases from one of its basic oxygen steelmaking furnaces. This Motor Challenge Showcase Demonstration project reduced fan energy use by nearly $50 \%$, saving just over $\$ 600,000$.

Variable frequency drives can be applied to any ventilation or fan system requiring variable output to meet changing demands. VFDs can also be used to improve performance of blowers, pumps, compressors, mills, conveyors, and other industrial systems.

\section{Benefits}

- Nearly $50 \%$ reduction in energy use

- Annual cost savings of $\$ 620,000$

- Less noise in the furnace area

\section{RESEARCH, SERVIGES} AND RESOURCES

\section{DOE programs support Steel Industry of the Future}

\section{OIT's Industries of the Future strategy accelerates $R \& D$ of novel technologies of interest to nine energy-intensive industries: aluminum, chemicals, forest products, glass, metalcasting, mining, petroleum, renewable bio-products, and steel. The strategy is sponsored and facilitated by OIT, a unit of DOE's Office of Energy Efficiency and Renew- able Energy. The focus is on developing high-risk, high-payoff, precompetitive technologies within a 20-year planning time frame.}

As an integral part of the Steel Industry of the Future strategy, OIT offers a range of programs that can help the steel industry begin saving energy, reducing costs, and cutting pollution right away. Using an "integrated delivery" approach, OIT seeks to make individual companies aware of all the potentially applicable technologies, tools, and expertise in OIT's extensive portfolio of products and services and then provide the right services to meet each customer's needs.

\section{Enabling Technologies}

Advanced Industrial Materials (AIM) develops and commercializes ${ }^{2 m}$ new and improved materials to increase energy efficiency, improve : productivity, and enhance material longevity and product quality.

The Combustion program increases productivity, improves energy efficiency, reduces emissions, and enhances fuel flexibility by developing cost-effective and energy-efficient technologies that are necessary for global competitiveness.

Continuous Fiber Ceramic Composite Materials pursues ceramic composite technologies that improve productivity by using higher process temperatures, extending component and system lifetimes, and reducing downtime.

Sensors \& Controls develops and deploys integrated measurement systems for operator-independent control of the manufacturing process. Priority goals are improving technology in sensors embedded in high-temperature and harsh environmental applications and in developing information processing to synthesize data from diverse sensors to detect and remedy malfunctions.

\section{Distributed Generation Technologies}

Advanced Industrial Energy and Power Systems improves the efficiency of fuel use and reduces overall emissions. This program supports extensive research, development, and demonstration to meet the technical and market challenges associated with industrial cogeneration and moderate-sized independent power production opportunities. 


\section{Financial Assistance}

The Inventions \& Innovation program provides financial assistance for establishing technical performance and conducting early development of innovative ideas and inventions. Ideas with potential for significant energy savings and commercial use are chosen for financial support through a competitive solicitation process. Technical guidance and commercialization support are offered to successful applicants.

National Industrial Competitiveness through Energy, Environment, Economics (NICE ${ }^{3}$ ) is an innovative cost-sharing program that promotes energy efficiency, clean production, and economic competitivenss in industry by providing funding to state and industry partnerships for technology demonstration projects.

\section{Technical Assistance}

Combined Heat and Power Challenge is focused on overcoming major barriers that currently exist in implementing combined heat and power systems, including complex and costly environmental permitting, unclear environmental regulations, excessive utility fees and rates, and long and varied Federal tax depreciation schedules.

Compressed Air Challenge is dedicated to improving the efficiency and performance of industrial compressed air systems with the goals of reducing energy use and costs.

Industrial Assessment Centers (IACs) help small and mediumsized manufacturers identify opportunities to improve productivity, reduce waste, and save energy through comprehensive industrial assessments. Teams of engineering professors and students from 30 universities across the country conduct the assessments and provide recommendations to manufacturers at no cost.

Motor Challenge helps increase the productivity and reliability of electric-motor-driven systems, reduce energy costs, and improve the bottom line by providing reliable, unbiased information, tools, and technical assistance to improve motor system efficiency.

Steam Challenge provides information tools and technical assistance that can help industry enhance productivity, lower production costs, and reduce emissions of its industrial steam systems.

\section{Additional information resources include:}

IPLocator (www.oit,doe,gov/locator) provides access to information on federally sponsored $R \& D$ projects that are ongoing or recently completed, optimizing the complementary research and development strengths of industry, universities, National Laboratories, and government.

OIT's Resource Catalog describes over 400 publications and other information products of interest to our customers. The catalog is available by calling 202-586-2090 or on the Web at www. oit.doe.gov/catalog.

\section{HOW TO GET INVOLVED}

mand Turning vision into reality

For U.S. steel companies, Industry of the Future partnerships can bring clear competitive advani- tages. Participating steel companies benefit from the reduced cost and risk of collaborative $R \& D$ and streamlined access to Federal scientific $=$ resources. Positioned at the forefront of technology development, these companies reap the benefits of more efficient and productive technologies and, in turn, contribute to our Nation's energy efficiency, industrial competitiveness, and environmental quality.

\section{Ways to participate}

By aligning $R \& D$ resources within industry and government to meet industry priorities, the Steel Industry of the Future will be poised to compete more effectively than ever in the global market.

There are many ways to participate:

- Monitor our Web pages for news and announcements of R\&D solicitations (www.oit.doe.gov//OF/steel).

- Team with other organizations and respond to solicitations for cost-shared research issued by OIT's Steel Industry of the Future team, our Enabling Technologies programs, and our Financial Assistance programs.

- Begin saving energy, reducing costs, and cutting pollution in your plant today by participating in any of the Technical Assistance programs.

- Call Marilyn Burgess, manager of OlT's Resource Room (202-586-2090), to learn more about the listed activities and

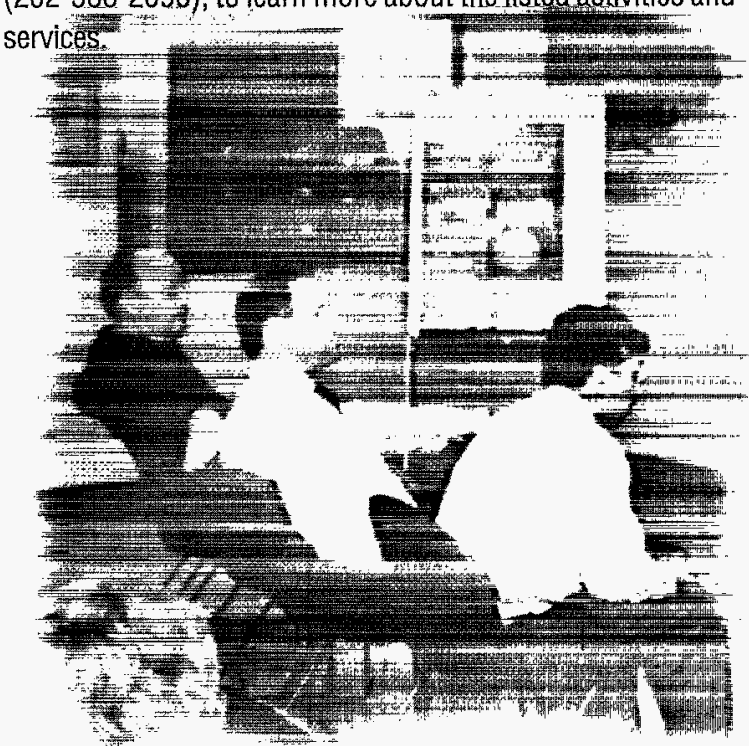

